\title{
PRAYER AS THE BEST WAY OF KNOWING GOD: BEN SIRACH IN ITS JEWISH CONTEXT AND IN LATER CHRISTIAN LITERATURE
}

\author{
Rev. Lect. PhD. Cătălin VATAMANU \\ Faculty of Orthodox Theology, Al.I. Cuza University of Iași \\ https://doi.org/10.47433/tv.xcvn9-12.111
}

\begin{abstract}
The first prayer of Ben Sirach (Sir. 22, 27-23:6) stands out for being a request addressed to God to guide his thoughts, words and deeds. Sirach refers to God as a very familiar person, "Lord, father, and sovereign ruler of my life". The understanding of the divine fatherhood in Sirach 23, 1.4 is enlightened by Sirach 4, 10; 51, 10, and by many other ancient Judaic sapiential texts. This terminology influenced the Liturgy of Early Church and the Fathers of the Church emphasized that the essential way to know God is the prayer.
\end{abstract}

Keywords: Ben Sirach, Old Testament Theology, prayer, education, knowing God, Judaism, Fathers of the Church.

\section{Premises}

In the Christian canon of the Old Testament, the book of Ben Sirach is located among the writings Anagignoskomena, considered good to read, but not normative for defining and affirming the faith. Therefore, the Holy Fathers and Writers of the Church approached texts and theological themes from it more from a moral or sapiential perspective. But Ben Sirach is not necessarily a writing of wisdom, philosophizing about life, but rather a writing strongly grounded in human life experiences. Therefore, some scholars ${ }^{1}$ of the holy text rightly believe that texts from Ben Sirach, if not the entire book, functioned as school texts with a fundamental role in the elementary, secular, but also religious education of children.

${ }^{1}$ T. Middendorp, Die Stellung Jesu Ben Siras zwischen Judentum und Hellenismus, Leiden, 1972, p. 32. H.V. Kieweler, Ben Sira zwischen Judentum und Hellenismus, BEAT 30, P. Lang, Frankfurt a.M. - New York, 1992, pp. 37-47. 
The importance of the book's message to the Jewish community stems, therefore, from the power of living theology presented here. Sirach is not a book that describes the religious identity, but shows how man's relationship with God works. In this context, the topic of our research is of utmost importance, because Ben Sirach emphasizes prayer as the most natural way of communication between God and man, but also the most appropriate way to know God. Therefore, the prayer that starts from the soul leads man to the mysteries of his creation and of the whole cosmos, to the knowledge of his Creator and Saviour.

The book of Ben Sirach cannot be ripped from the context of its writing, the Hellenistic period. Philosophical and religious ideas of the Hellenistic world can be discovered here, proving the major influence that Greek thought had in the second century BC, but especially before the Maccabean revolt ${ }^{2}$. Through this cultural and theological synthesis, Ben Sirach asserts himself in the context of Jewish literature as one of the representative books of early Palestinian Judaism, whose teaching laid the foundations of later rabbinic sects.

In order to decipher the theological message of the book, we must consider a few premises, without which the uninformed reader would remain in the cloak of literality, in the external appearance of the text. First of all, the reader of Ben Sirach must be familiar with biblical theophany symbolism and, in particular, with the ancient sacred traditions of the desert. Many Hebrew terms have multiple theological meanings, and some expressions, seemingly banal to someone unfamiliar, are enshrined in biblical mystical theology. But, as we will see in the last part of this study, the discovery of the meanings of mystery can only be through prayer, through theoria, the discovery by God of those hidden from man, as the Holy Fathers tell us. Second, this biblical language that we often find related to God is applied in Ben Sirach to wisdom as a divine manifestation. Wisdom dwells in the heavens, but she descends to the earth as the darkness of the clouds and

${ }^{2}$ G. von Rad, Weisheit in Israel, Neukirchen, 1970. E. Janssen, Das Gottesvolk und seine Geschichte, Neukirchen, 1971. H. Stadelmann, Ben Sira als Schriftgelehrter, WUNT 2/16, Tübingen, 1980. E.J. Schnabel, Law and Wisdom from Ben Sira to Paul, WUNT 2-16, Tübingen, 1985. 
a cloudy pillar and puts his throne in the temple of Zion. From this flows the third premise of our research: the accessibility of wisdom. Wisdom is close to man, it is at hand, it is easily accessible to man through prayer and through the reading of the Torah.

\section{The word of God comes out of the mouth of God and works in creation}

God's encounter with man is a personal one in Christianity, in which one reveals himself to the other by word. Therefore, the Church emphasizes the doxological role of communicating with God, through prayer, on the liturgy of the word in which one is brought to another, God descending from heaven and raising man to the capacity of His encounter. About this descent into the earth of the divine word as wisdom speaks Sirach 24, 3: „I came out of the mouth of the most High, and covered the earth as a cloud". It is obvious here that wisdom has its origin and lives in "the mouth of the most High", from where it descends over creation. This praise of wisdom reminds us of the Song of Wisdom from Prov. 8, but especially v. 23: „He established me before the time was in the beginning, before he made the earth." Both texts speak of the divine origin of wisdom, of its supertemporality and superspaciality. In addition, the personal character supports the possibility of communicating it to creation, especially to the chosen people whose history determines it. The prophet Isaiah refers in numerous texts to God's secret plan with the people of Israel, as in Is. 48,6 , a plan that is only partially discovered and understood by humans. Even though God reveals His will through His chosen people, prophets and hagiographers, through prophetic speeches and writings of wisdom, yet the man has not always received them as coming from heaven, as imperative. Therefore, God shows that $\mathrm{He}$ is the master of history, in which He is continually present and in which He reveals to man as divine wisdom (Is. 43, $1-19 ; 46,8-11 ; 48,3.5 .16 ; 55,11)$. Wisdom springs from the deepest mystery of the Holy One (Is. 48, 6b: „I have shewed thee new things from this time, even hidden things, and thou didst not know them") and rests in righteousness forever, says Isaiah in 45, 23 and 55, 11: "I have sworn by myself, the word is gone out of my mouth in righteousness, and shall not return"; ,"So shall my word 
be that goeth forth out of my mouth: it shall not return unto me void, but it shall accomplish that which I please, and it shall prosper in the thing whereto I sent it.". God's knowledge is not at hand of man and is beyond man's understanding. It is an act of discovery, as a result of divine mercy, towards the man who, through prayer, is open to knowledge. Therefore, God is the reason for our history, prophetically revealed in a special place and time. This is the key to reading Old Testament texts.

Unlike Prov. 8, Sirach does not make a simple statement about the origin of wisdom, but talks about how creative is she in creation. The word that descends creatively from heaven and spreads over the earth, shaping and transforming it, is the same working Word in Genesis 1, 2; 2, 6: "The earth was without form, and void; and darkness was on the face of the deep. And the Spirit of God was hovering over the face of the waters". We cannot overlook this ancient Israelite theology about the dwelling of God in the heavens, in the heights of the sky, from where He works the good for the cosmos and man. This theology is specific to Psalms 113, 4.5; 132, 14, but also to the prophet Isaiah 33, 5.16; 57, 15. As Sir. 24, 3b says, God „,covered the earth as a cloud”. In the biblical imaginary, God is like a cloud, full of mystery and hiding much higher realities, or the shadow of a cloud, which darkens the earth. The metaphor of the cloud, used to define the dwelling of God in heaven, is also found in iconographic representations. Texts that refer to God's dwelling in the dark cloud, or simply in the deepest darkness (like 1 Ki. 8:12 „Then spoke Solomon: The Lord hath said that He would dwell in the thick darkness."), they are obviously the source of inspiration for artists. The theophanic symbolism expressed by "darkness, clouds and smoke" is the typical mode of God's revelation, like that of God in Sinai (Exodus 20, 16-19). Therefore, the psalmist exclaims: „Clouds and darkness are round about Him; righteousness and justice are the foundation of His throne" (Psalm 97, 2). The cloud hides the high places (Sir. 24, 4), the Kingdom of God, His palace, in which He sits on the throne, ruling, a sign that the divinity cannot be circumscribed to the created space, be it a cult one: "The heaven is My throne, and the earth is My footstool" (Is. 66, 1; Ezek. 43, 6-7 and Ps. 103, 19). Therefore, the „pillar of cloud" is the proof of the connection between heaven and earth, 
between God and man (Is. 6, 1 and Ezek. 10,1), the testimony of the visible presence of God (Exodus 13, 21; 33, 9-10; Ps. 99, 7).

The „Pillar of cloud” remembers at the wandering through the desert and is a characteristic symbol of divine guidance and presence of God in the desert. If in Numbers 10, 33-34 the cloud of God accompanies Israel without home to a place of rest, the wisdom, on its throne, in a pillar of cloud, moves with Israel and, like Israel, seeks a place of rest (Sir. 24, 7) and find it in the holy city, in the Holy Temple (Sir. 24, 10-12) and in a worthy people (v. 12): „I, the Lord, search the heart, I test the mind, even to give every man according to his ways, According to the fruit of his doings (...). A glorious high throne from the beginning Is the place of our sanctuary." According to Sirach 24, 13-17, the wisdom is rooted in Sion, serves in the temple, blooms and gives fruit like the plants.

Again, Sirach 24 reminds us of the narrative about the Edenic Paradise of Genesis 2. Jerusalem is like the first garden (Genesis 2, 9; comparing with Ezek. 31, 2-9) and Ezekiel states in chapters 40-48 that Zion is the New Paradise. Here, the wisdom flows like Paradise rivers (Sir. 24, 25-27, Gen. 2, 10-14) through Torah.

\section{Wisdom is accessible to man through prayer}

As shown above, Sirach 24 suggests a restoration of Jerusalem as Paradise, whose plants are virtuous people, who wishes to grow in wisdom. The beautiful relationship between wisdom and the priestly ministry is evident here. The manifestation of wisdom is related to the cultic space and to the cultic doxology.

The darkness and the pillar of fire in Sir. 24, 3-4 are theophanic symbols associated with the sanctuary. The wisdom, like the priests, is placed in the tent in Sion (v. 8). Wisdom serves in the holy tabernacle (v. 10). Finally, it appears as oil and incense administered by the priest. In Exodus 30, wisdom is described as holy oil (Exodus 30, 31) and incense smoke (Exodus 30, 34), images that come back in Sirach 24, 15: „I gave a sweet smell like cinnamon and aspalathus, and I yielded a pleasant odour like the best myrrh, as galbanum, and onyx, and sweet storax, and as the fume of frankincense in the tabernacle". Sirach gives us here an excellent example of how the hagiographer synthesizes and rereads old biblical traditions. Referring to the vocabulary from Exodus 30, 
Sirach associates the presence of wisdom in Israel with the earthly tent and describes wisdom as the smoke of incense in the tent.

In his book, Sirach shows that he is not an anticlericalist, that he is not against cultic practices, and that is why he speaks of the importance of worship, of sacrifices, as we read, for example, in Sir. 7, 29-31: „Honour the priests and offer sacrifices”. Therefore, wisdom is not made an abstract principle, but has a concrete function within the cult ${ }^{3}$. Sirach is not trying to reduce the sacrificial system to a moral lesson. In this idea, Sirach 24, 15 demonstrates once again that wisdom is not an antithetic practice of cult.

\section{What we learn about God in the prayer of Sirach? An intertextual approach to the confession of Divine Paternity}

\section{a. God is Father - an old Israelite faith}

In praying for discipline of the tongue, Sirach invokes God: „O Lord, Father and Master of my life” (Sir. 23, 1), „O Lord, Father and God of my life" (Sir. 23, 4).

In the Hebrew Scriptures, God is Father of the people Israel (Deut. 32, 6; Ps. 68, 6; Is. 63, 16; 64, 7; Jer. 3, 4.19; 31, 9; Mal. 1, 6; 2, 10), for „Israel is my firstborn son" (Exodus 4, 22; compare with Deut. 1, 31 and Hos. 11, 1). Yahweh's image as the "father" for the people Israel constitutes in the Hebrew Bible one of the metaphors often used to argue the idea of election and pronation. Drawing directly from it, Israel's filiation is expressed through rights and responsibilities that the covenant "father-son" becomes in the Old Testament synonymous with a "Teacher-Disciple” agreement.

By going through these biblical texts, we can easily see that their subject is generally God, present in the first person. Through direct revelation or through the intercession of the prophets, Yahweh is revealed to man as a "father," to whom the Israelite reports as ,"a son." The relationship „I-you” and „you-I” is a dialogue and both discussion partners participate personally in it.

Yahweh has always the initiative of dialogue, and the man's sinful state can only distort this relationship. God always remains

\footnotetext{
${ }^{3}$ Gerald T. Sheppard, Wisdom as a Hermeneutical Construct: A Study in the Sapientializing of the Old Testament, Walter de Gruyter, Berlin-New York, 1980, p. 59.
} 
a dialogue partner. Because He is the „Father," the dialogue requires a teaching. Because He is also God, dialogue brings the teaching that saves. This is the theology that is highlighted in the Scripture of the Old Testament and who confronts man and king with God ${ }^{4}$.

The personal relationship between God and man is also reflected in the way that the man receives the divine revelation. As the holy text shows, God's message is perceptible to men, in spite of his nothingness. The „word" of the Lord is not amorphous, it is not incomprehensible, because he, coming from heaven, is made accessible to men: „For this commandment which I command thee this day, it is not hidden from thee, neither is it far off. It is not in heaven, that thou shouldest say, Who shall go up for us to heaven, and bring it unto us, that we may hear it, and do it? Neither is it beyond the sea, that thou shouldest say, Who shall go over the sea for us, and bring it unto us, that we may hear it, and do it? But the word is very nigh unto thee, in thy mouth, and in thy heart, that thou mayest do it" (Deut. 30, 11-14).

God appears to the chosen people not as a legislator of the heavens, but He is understood anthropomorphically as the „writer" of the laws, as in the texts Deut. 5, 22; 9, 10; 10, 2; Exodus 31, 18. In Deut. 9, 10 appears the idea that the tablets of the Law were „written with the finger of God". Or, in other texts, the Law comes as a result of a dialogue: „Moses asked, and God answered him with a loud voice" (Exodus 19,19). The Torah of Yahweh comes to us directly: "The tablets were the work of God, and the writing was the writing of God Himself, engraved on the tablets" (Exodus 32:16).

The word of God has become accessible to us, and the man's duty is to hear and fulfil it. Making Yahweh's teaching accessible requires only a change of form and not a change of substance; the divine message remains divine and does not turn into a purely human one. This is the Divine pedagogy: to give man the possibility of receiving His message, for correction and not for destruction. „Did ever people hear the voice of God speaking out of the midst of the fire, as thou hast heard, and live?", asks the deuteronomist in Deut. 4, 33. The hagiograph further explains that the kenotic act

${ }^{4}$ Cătălin Vatamanu, The Israelite King - an anthropological key of the relation between god and man in the Hebrew Scripture, in " $6^{\text {th }}$ SWS International Scientific Conference on Social Sciences ISCSS", 2019, p. 64. 
of God, to descend to the level of understanding of men, was made out of love and as a result of the choice of Israel. The man has the duty to learn from these wonderful realities the uniqueness of Yahweh: „Unto thee it was shewed, that thou mightest know that the Lord he is God; there is none else beside him. Out of heaven he made thee to hear his voice, that he might instruct thee: and upon earth he shewed thee his great fire; and thou heardest his words out of the midst of the fire. And because he loved thy fathers, therefore he chose their seed after them, and brought thee out in his sight with his mighty power out of Egypt" (Deut. 4, 35-37).

Like a good teacher, Yahweh rebukes Israel whenever he wrongs, and expects his return from time to time: „If they break my statutes, and keep not my commandments; Then will I visit their transgression with the rod, and their iniquity with stripes. Nevertheless, my lovingkindness will I not utterly take from him, nor suffer my faithfulness to fail. My covenant will I not break, nor alter the thing that is gone out of my lips" (Ps. 89, 31-34, parallel to Deut. 8, 3, Job 9, 34). Ben Sira employs parental language when he depicts God's compassionate dealings with the human, including rebukes (Sir. 18: 13-14). The divine compassion exceeds human mercy: „Their compassion is for their neighbour, but the Lord's compassion reaches all flesh, reproving, admonishing, teaching, and turning them back, as a shepherd his flock. He has compassion on those who accept his discipline, who are eager for his precepts" (Sirach 18, 13-14).

In the literature of the diaspora of Hellenistic Judaism, God is addressed in prayer as Father in 3 Macc. 6, 4.8: „Pharaoh, the former ruler of this land of Egypt, with his multitude of chariots, showed great presumption with his arrogant actions and proud boasts. But you destroyed him along with his arrogant army. You drowned them in the sea and showed forth the light of your mercy to your people Israel. (...) And you, Father, looked upon Jonah, when he was wasting away in the belly of a sea monster from the depths, and you restored him unharmed to all his family". In the same book, He is called Father of the people Israel in 3 Macc. 5, 7 and 7, 6: „But with persistent cries and tears they all called upon their almighty Lord and merciful God and father, who rules over every power. They continued to pray"; ,Now we threatened them sternly for these actions, but we granted them their lives (but just 
barely!) in keeping with the patience that we show toward all people. Because we have learned that the heavenly God surely shields the Jews and fights alongside them as a father for his children". We find the same pedagogical dimension of the divine pronoun in a prayer for Intercession (3:5-8) at Qumran: ,So now, we beseech Thee, to the end that Thy great power may be known, and the abundance of Thy mercies also, unto all generations for ever, let Thine anger and Thy wrath be turned away from Thy people Israel, and, besides their sins, remind Thyself also of Thy peculiar favours which Thou hast (always) wrought for us in the sight of the nations, because Thou hast claimed us as Thine own. [Vouchsafe, we beseech Thee, to turn us again unto Thee with all our heart and soul, and so to plant Thy teaching in our hearts" ${ }^{5}$.

\section{b. God is merciful and gracious - as a theological experience in the history of the chosen people}

When he is in distress, Sirach uses the language specific to King David's sonship with God to raise his prayer. Thus, Sirach seems to take literally the texts of 2 Sam. 7, 14, Ps. 2, 7 and Ps. 89, 27 (26) relating the theology of choice and providence to himself and calling God the Father: „He shall cry to me, 'You are my Father, my God, and the Rock of my salvation!" (Sir. 51, 1-12). According to the Hebrew text 51, 10, Sirach prays: "And I extolled the Lord, 'You are my Father, for you are my mighty salvation!'”.

Divine pedagogy cannot be separated from the Providence of God. There are many texts that speak of God's care for man, sometimes presented in the form of parents' concern for the well-being of their children. A very expressive text is Sol. 16, 20-21: „Instead of which things thou didst feed thy people with the food of angels, and gavest them bread from heaven prepared without labour; having in it all that is delicious, and the sweetness of every taste. For thy sustenance shewed thy sweetness to thy children, and serving every man's will, it was turned to what every man liked".

${ }^{5}$ Theodor H. Gaster, The Dead Sea Scriptures (with notes and introduction), 3rd revised and enlarged edition, Anchor Press, New York, 1976. The text is quoted after the electronic edition https://documento.mx/documents/dead-sea-scriptures-5c11801b6cfb3. 
Yahweh's responsibility to the children of Israel was understood primarily as a concern for food. The road through the Sinai desert is disturbed by the absence of food and water, and Yahweh is made responsible for this lack (Exodus 16, 8). Likewise, the promised land is the land where milk and honey flow (Exodus 3, 8). Another text suggests, in this regard, the attention that God paid to the people of Israel: „Who fed thee in the wilderness with manna, which thy fathers knew not, that he might humble thee, and that he might prove thee, to do thee good at thy latter end" (Deut. 8, 16).

In Jewish tradition, the mercy reflects the portrayal of God in the divine revelation to Moses (Exodus 20, 5; 22, 27; 33, 19; 34, 6). For example, Exodus 34, 6 seems to be reread by Sirach 2, 11: ,The Lord is merciful and gracious”. The adjectival noun „Merciful One" is used of God in Sir. 50, 19. However, some texts from the Pentateuch must be quoted in full here, in addition to the above:

Exodus 33, 19: „I will cause all My goodness to pass in front of you," the Lord replied, "and I will proclaim My name, the Lord, before you. I will have mercy on whom I have mercy, and I will have compassion on whom I have compassion".

Numbers 14, 18: „The Lord is slow to anger and abounding in loving devotion, forgiving wrongdoing and rebellion. But He will by no means leave the guilty unpunished; He visits the iniquity of the fathers upon their children to the third and fourth generation".'

Deuteronomy 4, 31: „For the Lord your God is a merciful God; He will not abandon you or destroy you or forget the covenant with your fathers, which He swore to them by oath".

Psalm 103, 8: „The Lord is compassionate and gracious, slow to anger, abounding in loving devotion".

Psalm 108, 4: „For Your loving devotion is higher than the heavens, and Your truth reaches to the skies".

And in Kethubim we encounter literary expressions of great theological beauty when the author talks about the great mercy of God. I stop at only two such literary arguments:

2 Chronicles 30, 9: „For if you return to the Lord, your brothers and sons will receive mercy in the presence of their captors and will return to this land. For the Lord your God is gracious and merciful; He will not turn His face away from you if you return to Him". 
Nehemiah 9, 17: „They refused to listen and failed to remember the wonders You performed among them. They stiffened their necks and appointed a leader to return them to their bondage. But You are a forgiving God, gracious and compassionate, slow to anger and rich in loving devotion, and You did not forsake them".

In the prophetic literature, God is described as merciful and loving especially in the context of the prophetic request for repentance of the people. Israel is a hostile and disobedient people, fulfilling divine commandments only formally. The prophetic call to a change of attitude, to a real conversion, is accompanied by the affirmation of faith in God's mercy and the sending of blessings, as in Isaiah 65, 16, Jeremiah 9, 24, Joel 2, 13 and in Jonah's prayer from 4, 2: „O Lord, is this not what I said while I was still in my own country? This is why I was so quick to flee toward Tarshish. I knew that You are a gracious and compassionate God, slow to anger, abounding in loving devotion”, in Jeremiah 32, 18: "You show loving devotion to thousands, but lay the sins of the fathers into the laps of their children after them, O great and mighty God whose name is the Lord of Hosts”, and Nahum 1, 3: „The Lord is slow to anger and great in power; the Lord will by no means leave the guilty unpunished".

The psalms have a special place in the biblical confession of God's mercy. God is "Father of orphans and protector of widows” in Ps. 68, 6, text than Sirach echoes in 4, 10: „Be like a father to orphans, and in place of a husband to widows, and God will call you son". Thus, he develops this understanding of prayer for wisdom as a way of discovering the way of the Lord, just as a father mercifully discovers in his son the good things in life. The mercy of God „is great unto the heavens, and thy truth unto the clouds" (Psalm 57, 10), „He shall cover thee with his feathers, and under his wings shalt thou trust: his truth shall be thy shield and buckler" (Psalm 91, 4). „For thy mercy is great above the heavens: and thy truth reacheth unto the clouds", affirms Psalm 108, 4.

Of course, these Old Testament theological ideas will be exceptionally exploited doctrinally by the Holy Apostles. For example, the Holy Apostle Paul, in Romans 2, 4, rhetorically asks: „Or do you disregard the riches of His kindness, tolerance, and patience, not realizing that God's kindness leads you to repentance?", to 
which the text of James 5, 11 seems to be a response synthesized as a confession of faith: „The Lord is full of compassion and mercy”.

\section{Knowing God through prayer. Some patristic and philokalik reflections}

The Holy Fathers have given us great works devoted to prayer, in which they show that prayer is the raising of the mind and heart to God. The Prayer is a dialogue with God. When praying the man converses with God. The Holy Apostle Paul urges us: „Speaking to yourselves in psalms and hymns and spiritual songs, singing and making melody in your heart to the Lord" (Ephesians $5,19)$. In everything the Apostles did, they thought of God and lived in constant devotion to Him. In the early Church, worship was inseparable from doctrine as reflected in the statement: lex orandi, lex credendi. Every act of worship was and is a form of prayer.

The Church writers, the Holy Fathers, and philocalical writers have shown in their writings that the best way to know God is through prayer. In this encounter of the humble man with the love of God takes place the revelation, the knowledge of the divine mysteries that sanctify the man. And to highlight these theological realities in the tradition of the Church, we will quote below some representative texts.

„Fire makes iron impossible to touch, and likewise frequent prayer renders the intellect more forceful in its warfare against the enemy. That is why the demons strive with all their strength to make us slothful in attentiveness to prayer, for they know that prayer is the intellect's invincible weapon against them" ${ }^{\prime 6}$.

"Someone may indeed dare seek intimacy with God while yet knowing himself to be in need of purification, discerning that his wicked conscience is filled with stains and evil wounds. If such a person, prior to being cleansed from these many evils, approaches

${ }^{6}$ Ale cuviosului Părintelui nostru Ioan Carpatiul, Una sută capete de mângâiere către monahii din India cari i-au scris lui, 76, in Filocalia cari arată cum se poate omul curăți, lumina şi desăvârşi, vol. IV, translated from Greek by Prot. stavr. Dr. Dumitru Stăniloae, Tipografia Arhidiecezană, Sibiu, 1948, p. 148. The text is quoted after the English edition The Philokalia: the Complete Text, vol. I, by St. Nicodemos of the Holy Mountain and St. Makarios of Corinth, trans. by G.E.H. Palmer, Philip Sherrard, and (Bishop) Kallistos Ware, Faber and Faber, London, 1979, ebook edition, 2010, pp. 460-461. 
God to call Him 'Father', it would be like a person who is unjust and impure, and yet dares to address the One who is Most just and pure. It would be, at it were, to name God as the Father of one's own wickedness, a flagrant insolence. Such a person's words would amount to no less than mockery. Why? Because the word 'Father' signifies fatherhood - the source and cause of a person who is made to exist by God. Therefore, whoever invokes God as Father and still possesses a wicked conscience, he in fact accuses God of nothing less than being the source and cause of his own evils. According to the apostle Paul, however, 'there is no communion between light and darkness' (2 Cor 6, 14). Rather, the contrary is true. The light seeks intimacy, with what is just, the good with what is good, the incorruptible with what is incorruptible. The opposite things seek intimacy with their own kind. The Lord said: 'A good tree cannot bear bad fruit, nor can a bad tree bear good fruit' (Mt 7, 18). If someone is possessed, as Scripture puts it, by hardness of heart and dares to utter the words of the Lord's Prayer, he pursues falsehood. Let him know that such a person calls Father not the Heavenly One, but the Infernal One. The latter is himself a liar and the father of lies $(\mathrm{Jn} 8,44)$ that may arise in any given person. He is $\sin$ and the father of $\sin ^{\prime \prime}$.

"Intelligent silence is the mother of prayer, a recall from captivity, preservation of fire, an overseer of thoughts, a watch against enemies, a prison of mourning, a friend of tears, effective remembrance of death, a depicter of punishment, a delver into judgment, a minister of sorrow, an enemy of freedom of speech, a companion of stillness, an opponent of desire to teach, increase of knowledge, a creator of divine vision, unseen progress, secret ascent" ${ }^{\prime 8}$.

${ }^{7}$ Sfântul Grigorie de Nyssa, Despre rugăciunea domnească, Cuvântul II, in Sfântul Grigorie de Nyssa, Scrieri, I, col. PSB, vol. 29, Editura Institutului Biblic și de Misiune al Bisericii Ortodoxe Române, Bucureşti, 1982, p. 418. The text is quoted after the English edition St. Gregory of Nyssa, On The Lord's Prayer, Homily 2: „Our Father Who Art in Heaven”, translated by Theodore G. Stylianopoulos, 2003, text available on the internet at https://www.orthodoxprayer.org/Articles_files/GregoryNyssa-Homily2\%20Lords\%20Prayer.html.

${ }^{8}$ Sfântul Ioan Scărarul, Scara, „Cuvântul al unsprezecelea”, translated from Greek, Predania, Bucureşti, 2008, p. 178. The text is quoted after the English edition St. John Climacus, The Ladder of Divine Ascent, Step 11: „On Talkativeness and Silence", Holy Transfiguration Monastery, Boston, 1978, text available on the internet at http://www.innerlightproductions.com/2012/09/st-john-climacuspart-iii-steps-7-12-of.html. 
"The enemy knows that prayer is our invincible weapon against him, and so he tries to keep us from praying. He fills us with a desire for secular learning, and encourages us to spend our time on studies that we have already renounced. Let us resist his suggestions; otherwise, if we neglect our own fields and go wandering elsewhere, we shall harvest thorns and thistles instead of figs and grapes. 'For the wisdom of this world is folly in God's sight' (I Corinthians 3, 19)"

"Those whose mind has learned true prayer converse with the Lord face to face, as if speaking into the ear of the emperor. Those who make vocal prayer fall down before Him as if in the presence of the whole senate. But those who live in the world petition the emperor amidst the clamor of all the crowds. If you have learned the art of prayer scientifically, you cannot fail to know what I have said" ${ }^{\prime 10}$.

„Persevere with patience in your prayer, and repulse the cares and doubts that arise within you. Try to make your intellect deaf and dumb during prayer, you will then be able to pray"11.

\section{Conclusions}

Ben Sirach's book fits literary and theological in the expression of faith in God as a merciful and loving Father, ready to guide the man to a virtuous life. Chapter 24 begins with a song of wisdom in relation to creation. The wisdom is in heaven and speaks of its origins in a manner similar to Proverbs 8 . Next, the narrative brings the theme of the catabasic journey of wisdom, in search of rest and inheritance, which coincides with the time when Moses received the Torah from above, from God, from Mount Sinai, and handled it over to the people of Israel. Wisdom dwells in the holy tabernacle and then in the Temple of Sion. The centre of attention, in the

${ }^{9}$ Ale cuviosului Părintelui nostru Ioan Carpatiul..., p. 127. The text is quoted after the English edition The Philokalia..., ed. cit., vol. 1, p. 438.

${ }^{10}$ Sfântul Ioan Scărarul, op. cit., p. 360, apud ed. cit.

${ }^{11}$ Evagrie Ponticul, Cuvânt despre rugăciune, în Filocalia cari arată cum se poate omul curăţi, lumina şi desăvârşi, vol. I, ediția a II-a, translated from Greek by Prot. stavr. Dr. Dumitru Stăniloae, Institutul de Arte Grafice „Dacia Traiană”, Sibiu, 1947, p. 76. The text is quoted after the English edition of Evagrios the Solitary, On Prayer, in The Philokalia..., ed. cit., vol. 1, p. 63. 
midst of God's place of honour, is wisdom, which is the Torah (Sirach 24,23$)$.

Our research has led to the conclusion that the apostolic and patristic theological expression of the manifestation of God as Father, which man discovers as Merciful and Loving through the dialogue of prayer, is precisely the development of a fundamental theme of the Old Testament and, in particular, of the book of Ben Sirach. This understanding expressed theologically in the context of the Exodus from Egypt and the inhabitation of the Holy Land, later in the times of the Davidic monarchy and the prophetic times is therefore based on the living experience of man's encounter with God in history and, hidden, in the prayer, as Saint Paul said: „Blessed be the God and Father of our Lord Ben Christ, the Father of mercies and the God of all consolation, who consoles us in all our affliction" (2 Cor. 1, 3-4).

\section{Acknowledgements}

This work was carried out within the project „Development of innovation capacity and increasing the impact of research excellence at UAIC" funded by the Ministry of Research and Innovation through Program 1 - Development of the national research and development system, Subprogram 1.2 - Institutional performance Funding projects of excellence in RDI, Contract no. 34PFE / 19.10.2018"

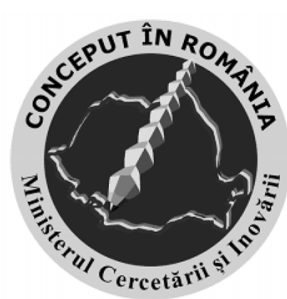

Această lucrare a fost realizată în cadrul proiectului „,Dezvoltarea capacității de inovare și creșterea impactului cercetării de excelență la UAIC" finanțat de Ministerul Cercetării și Inovării prin Programul 1 - Dezvoltarea sistemului național de cercetare-dezvoltare, Subprogram 1.2 - Performanță instituțională Proiecte de finanțare a excelenței în CDI, Contract nr. 34PFE/ 19.10.2018. 